\title{
Impasses na constituição do sujeito
}

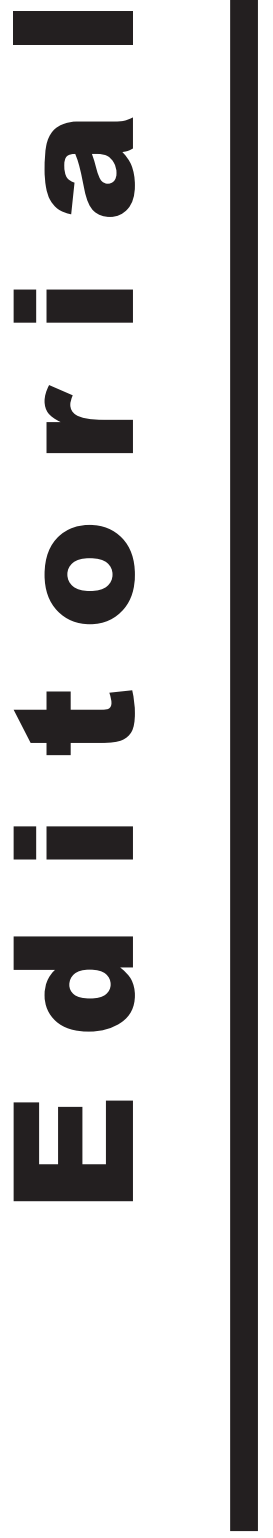

Assumir que há uma constituição do sujeito e que nela podem ocorrer impasses, mais do que a descrição rigorosa de uma pretensa realidade e sua consequente formalização científica, é propor uma fórmula com a qual operar com o real.

Coube a Lacan, em particular em seu texto "A ciência e a verdade", demonstrar que, ao contrário do que crê o espírito positivista - tomado desde a modernidade como o verdadeiro espírito científico da ciência -, a operação fundamental do trabalho científico não é a decifração da realidade, mas, antes, uma cifração com a qual se opera com o real.

Por mais que pareça que a verdade estaria colada na realidade e que caberia à ciência apenas desvelá-la em sua forma fixa e invariável, vemos que ela - a verdade - deve, antes, ser buscada no jogo de palavras que utilizamos para operar com o real. Pois bem, a seguirmos com essa definição, somos obrigados a constatar, mesmo a contragosto dos positivistas, que a ciência tem um sujeito, aquele mesmo que a ciência moderna tentou evacuar de seu campo por entendê-lo como uma anomalia ao saber científico, posto que traria sua singularidade instável para um terreno no qual se busca uma regularidade estável.

Para a ciência moderna só poderíamos compreender os desacordos tão frequentes na comunidade científica como resultantes do engano daqueles que ainda não perceberam corretamente a realidade: a verdade está garantida por Deus, o homem é que pode se enganar, acreditava Descartes. É, portanto, da miopia do homem, em sua imperfeição, que devemos duvidar e a ciência deve dar-lhe os óculos que faltam para melhor ver o que foi escrito por Deus.

A novidade herética introduzida por Lacan, nesse sentido, foi a de demonstrar que a garantia da verdade se é que a verdade garante algo - está do lado do sujeito: não há verdade sem um sujeito que a engendre.

Talvez se possa pensar que foi a percepção, ainda que nebulosa, dessa ligação funesta entre sujeito e verdade que 
levou a ciência a expulsá-lo de seu campo, inclusive para que este pudesse se constituir. Quando se busca um campo estável, seguro, deve-se estar prevenido contra o sujeito. Nisso não se pode reprovar a decisão da ciência: onde há sujeito há impasse.

Com a psicanálise nos demos conta de que esse sujeito - perturbador não é um dado da natureza: ele se constitui. Contrariamente à grande parte do pensamento filosófico e científico, para a psicanálise, a cria humana não nasce inacabada, mas, antes, indeterminada.

A ideia de inacabado sugere que o que vem a seguir é da ordem do completamento de um texto - o texto genético - cuja forma inicial, já escrita, é determinante para sua continuidade. Por força dessa ideia, o conceito de desenvolvimento, tão caro à biologia, onde nasceu, ganhou terreno espraiando-se para outros campos, em particular à psicologia.

Já a ideia de indeterminado implica pensar não que não haja nada no ponto de partida, mas que o que há no ponto de partida não assegura nenhum movimento retilíneo uniforme para o percurso. Ainda que haja algo já escrito, é o que será inscrito no percurso que definirá o texto que vai valer.

Nesse sentido, isso que vem depois, e que vem como inscrição, não é da ordem do complemento do natural, mas do suplemento: o sujeito é suplementar à natureza.

Sua constituição não prolonga uma lógica pré-escrita, ao contrário, perturba essa lógica introduzindo nela outra legalidade, abrindo possibilidades que só a noção de destino - tão cara a Freud no desenvolvimento de seu conceito de pulsão - pode contemplar. Se o sujeito se abre a um destino é porque não está predeterminado.

A célebre figura de Victor de Aveyron - o menino selvagem - personagem fundamental na história das ciências humanas, tornou-se o exemplo paroxístico dessa indeterminação de saída. A lição essencial que se pôde tirar de sua história é que nem mesmo a humanidade, que sempre se acreditou estar escrita e garantida pelo texto genético do homem, está assegurada, livre do peso dos acasos.

Dessas diferentes compreensões do humano derivam diferentes concepções daquilo que o define, bem como diferentes modos de trabalhar com ele. Os recentes debates entre a psicanálise e a psiquiatria em torno da definição do campo das patologias é uma prova ilustrativa dessa diferença.

A noção de transtorno - tornada peça-chave na lógica diagnóstica nos manuais diagnósticos - ganhou celebridade no campo da psiquiatria. Aparentemente, ela foi concebida para evitar os inconvenientes da ideia de desvio, herdeira da ideia de norma, sempre inevitavelmente moralizante. Moralização que coube a Canguillhem, em seu célebre livro O normal e o patológico, tão bem desmontar.

Diferentemente da física, por exemplo, para a qual o conceito de norma não faz nenhum sentido, para a biologia, ele é central e constitui a entrada de um valor no campo suposto neutro da descrição do fenômeno. 
Com a noção de transtorno se optaria por uma visada puramente descritiva, livre das querelas interpretativas que se perdem em longas discussões estéreis sobre a etiologia e a semiótica dos sintomas. Mas transtorno em relação a quê?

Resulta interessante imaginar o diagnóstico que poderia ter sido dado a Victor de Aveyron - que, na época, foi diagnosticado como retardado severo -, segundo os critérios diagnósticos atuais na psiquiatria. Transtorno de espécie, talvez. Quem sabe? Para além da provocação, a hipótese mais provável é que ele fosse diagnosticado como politranstornado, o que já mostra o embaraço da psiquiatria em evacuar de seu campo qualquer valoração para além da descrição do quadro.

Com esse diagnóstico veríamos Victor entrar numa série genérica e asséptica que faria perder todo o valor singular que sua história agregou para o conhecimento humano. O politranstornado é um diagnóstico estatisticamente muito frequente. Sua frequência significativa nos leva a pensar que a precisão buscada com o novo método diagnóstico talvez leve a uma imprecisão que necessita ser compensada com a multiplicação de diagnósticos. Como o sujeito não cabe em uma categoria diagnóstica, é melhor o colocarmos em várias. É isso mesmo: o sujeito é aquilo que resiste/excede a toda classificação.

Com a noção de impasse, a psicanálise escolhe outra via de compreensão. Um impasse é a detenção de um sujeito num conflito do qual se pode esperar uma saída, um passe. A constituição do sujeito é feita de impasses cuja consequência é a construção de uma história particular, irrepetível: é cifração. Nessa perspectiva, o que vai se cifrar nessa história depende dos incidentes vividos ou, como se convencionou dizer na teorização psicanalítica: do acaso como causa.

De tal forma, uma história como a de Victor, assim como todas as outras, deve ser entendida no fio de seus impasses constitutivos, nos quais se pode encontrar não a causa de seus sintomas - pergunta, ao contrário do que se pensa, sempre pouco importante para um psicanalista - mas a razão da inércia destes, porque é aí que a possibilidade de algum passe pode vir a ser descoberta.

Neste dossiê o leitor encontrará bons exemplos das discussões que se dão no interior dessa querela constituída a partir desses dois modos de compreender o humano e seu sofrimento. $\mathrm{O}$ sujeito entre o saber médico, psiquiátrico e o saber psicanalítico gera mesmo boas discussões. Esperamos que esse debate, que está longe de encontrar um bom termo, funcione verdadeiramente como um debate sem sucumbir à querela, forma mais deletéria de uma discussão que não leva senão ao entrincheiramento em lados que não se ouvem mais porque restou apenas, a cada um deles, a tarefa de atacar.

Rinaldo Voltolini 